\title{
Penerapan Metode Delphi dan Servqual untuk Perbaikan Mutu Pelayanan di Plasa Telkom Sitiung
}

\author{
Ekie Gilang Permata, ST, M. Sc ${ }^{1}$, Andre Okta Viendra ${ }^{2}$ \\ 1,2 Jurusan Teknik Industri, Fakultas Sains dan Teknologi, UIN Sultan Syarif Kasim Riau \\ Jl. HR. Soebrantas No. 155 Simpang Baru, Panam, Pekanbaru, 28293 \\ Email: ekiegp@yahoo.com oktaviendra@gmail.com
}

\begin{abstract}
ABSTRAK
Plasa Telkom Sitiung merupakan salah satu perusahaan yang melayani masyarakat khususnya di bidang telekomunikasi. Penelitian ini bertujuan untuk menentukan perbandingan antara tingkat persepsi dengan tingkat harapan yang diberikan, penyebab ketidakpuasan pelanggan, serta memberikan usulan perbaikan untuk meningkatkan kualitas pelayanan. Hal ini diketahui hasil penyebaran kuesioner pendahuluan dengan persentase terbanyak yaitu $48 \%$ merasa tidak puas dan 33\% merasa cukup puas sedangkan $19 \%$ merasa puas terhadap pelayanan. Untuk mencapai tujuan digunakan integrasi metode Delphi, Service Quality (Servqual). Berdasarkan hasil pengumpulan, pengolahan dan analisis data yang telah dilakukan dapat diketahui ada 18 atribut kualitas jasa (5 atribut dimensi Tangible, 4 atribut dimensi Reliability, 3 atribut dimensi Responsiviness, 3 atribut dimensi Assurance, 3 atribut dimensi Emphaty) yang diinginkan oleh pelanggan untuk ditingkatkan. Berdasarkan analisis GAP, semua skor GAP bernilai negative sehingga tiap dimensi kualitas jasa masih perlu untuk diperbaiki dan ditingkatkan. Dimensi kualiatas jasa yang mendapat prioritas untuk perbaiki atau ditingkatkan adalah dimensi Tangible (selisih nilai GAP -0,48) dan dimensi Rsponsiviness (selisih nilai GAP -0,47).
\end{abstract}

Kata kunci: Perbaikan Mutu Pelayanan, Metode Delphi, Service Quality (Servqual)

\section{Pendahuluan}

Kualitas layanan sangat mempengaruhi kepuasan pelanggan, karena apabila kualitas layanan tidak sesuai dengan harapan konsumen, maka konsumen tidak akan puas. Hal tersebut secara tidak langsung akan mempengaruhi kualitas layanan yang dihasilkan oleh perusahaan.

Pelanggan yang puas cenderung tetap loyal lebih lama, membeli lebih banyak, kurang peka terhadap perubahan harga dan mereka akan membeli ulang dan memberitahu orang lain mengenai pengalaman baik dengan produk tersebut. Kualitas mempunyai dampak langsung terhadap prestasi produk atau jasa dan kepuasan konsumen atau pelanggan, sehingga semakin puas konsumenatau pelanggan maka kualitas pelayanan pada suatu perusahaan akan semakin baik pula atau berkualitas.

Kualitas pelayanan merupakan segala bentuk aktivitas yang dilakukan oleh perusahaan guna memenuhi harapan konsumen. Pelayanan sebagai jasa atau servis yang disampaikan oleh pemilik jasa yang berupa kemudahan, kecepatan, hubungan, kemampuan dan keramah-tamahan yang ditujukan melalui sikap dan sifat dalam memberikan pelayanan untuk kepuasan konsumen (Firdian, dkk, 2012).

Kepuasan konsumen atau pelanggan pada dasarnya mencakup perbedaan antara harapan dan kepentingan atau hasil yang dirasakan oleh konsumen/pelanggan. Dengan demikian kunci keberhasilan perusahaan sebenarnya sangat tergantung kepada suksesnya perusahaan dalam memuaskan kebutuhan pelanggannya (Suwandi, 2011 dikutip oleh Firdian, 2012).

Dalam pengukuran tentang kualitas pelayanan berdasarkan kepuasan pelanggan tercantum beberapa keputusan menteri salah satunya dalam Keputusan Menteri Negara Pendayagunaan Aparatur Negara Nomor 25/KEP/M.PAN/2/2004 tentang "Pedoman Penyusunan Indeks Kepuasan Masyarakat Unit Pelayanan Instansi Pemerintah". Sehingga unit pelayanan instansi pemerintah harus terus melakukan penyusunan indeks kepuasan masyarakat. 
Kuesioner pendahuluan disebarkan sebanyak 15 kuesioner kepada pelanggan di Plasa Telkom Sitiung. Adapun hasil kuesioner pendahulaun yang disebarkan dapat dilihat pada Gambar 1

\section{Grafik Kepuasan Pelanggan}

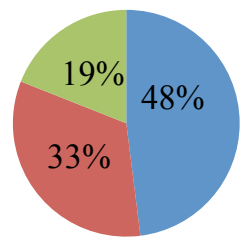

$$
\begin{aligned}
& \text { Tidak } \\
& \text { Puas } \\
& \text { Cukup } \\
& \text { Puas } \\
& \text { Puas }
\end{aligned}
$$

Gambar 1 Diagram Hasil Kuesioner Pendahuluan

Dari Gambar 1.1 dapat di lihat bahwa 48\% pelangan yang merasa tidak puas terhadap pelayanan yang diberikan oleh Plasa Telkom Sitiung dan 33\% pelangan yang merasa cukup puas dengan pelayanan Plasa Telkom Sitiung, 29\% pelangan puas terhadap pelayanan yang diberikan oleh Plasa Telkom Sitiung. Untuk itu Plasa Telkom Sitiung harus memperhatikan kualitas pelayanan yang diberikan agar pelangan merasa puas.

Metode Delphi merupakan suatu metode yang dilakukan dengan membentuk suatu kelompok atau komunikasi grup yang terdiri dari para ahli untuk membahas suatu permasalahan (Gordon, 1994; Linston and Turrof, 2002 dikutip oleh Sukawandi, 2013).

Metode Servqual (Service Quality) dikembangkan oleh (Zeithaml, 1990 dikutip oleh Handayani, 2006) menggunakan pendekatan userbased approach, yang mengukur kualitas secara kuantitatif dalam bentuk kuesioner yang mengandung dimensi-dimensi kualitas jasa, yaitu Tangibles, Reliability, Responsiveness, Assurance, Emphaty.

\section{Tinjauan Pustaka}

\section{Defenisi Jasa}

Kotler (1995) dikutip oleh Purnamawati (2014) definisi jasa adalah "Setiap tindakan atau kegiatan yang ditawarkan satu pihak pada pihak lain yang pada dasarnya tidak berwujud dan tidak mengakibatkan kepemilikan apapun. Produksi jasa dapat atau tidak dapat berkaitan dengan produk fisik. Definisi layanan mutu menurut Affif (1994) dikutip oleh Purnamawati (2014) adalah "Berbagai tindakan atau kinerja yang ditawarkan suatu produk kepada orang lain yang pada dasarnya tidak dapat dilihat dan tidak menghasilkan hak milik terhadap sesuatu produksinya, dapat berkenaan dengan produk fisik atau tidak".

Jasa atau pelayanan merupakan suatu kinerja penampilan, tidak berwujud dan cepat hilang, lebih dapat dirasakan dari pada dimiliki serta pelanggan lebih dapat berpartisipasi aktif dalam proses mengkonsumsi jasa tersebut (Purnamawati, 2014). Dalam strategi pemasaran, definisi jasa harus diamati dengan baik, karena pengertiannya sangat berbeda dengan produk berupa barang. Kondisi dan cepat lambatnya pertumbuhan jasa akan sangat tergantung pada penilaian pelanggan terhadap kinerja yang ditawarkan oleh pihak produsen.

Ada tiga keputusan yang harus diambil pemasar dalam kaitannya dengan layanan kepada pelanggan antara lain (Purnamawati, 2014):

1. Pelayanan jasa-jasa apakah yang harus diberikan dalam melayani pelanggan pemasar perlu melakukan survei atas konsumen untuk mengidentifikasikan pelayanan utama yang mungkin ditawarkan dan arti penting relatifnya, misalnya potongan harga, pelayanan yang sopan dan ramah dan lain-lain.

2. Tingkat pelayanan yang bagaimana yang ditawarkan pelanggan tidak hanya menginginkan pelayanan tertentu tetapi juga pelayanan dalam jumlah yang cukup dan mutu yang memadai. Badan usaha perlu membandingkan pelayanannya dengan pelayanan yang diberikan oleh pesaingnya dan kaitannya yang diharapkan oleh pelanggan contoh adanya kotak saran dan sistem pelayanan keluhan.

3. Dalam bentuk apakah pelayanan itu harus diberikan pemasar juga harus mengambil keputusan mengenai bentuk dari berbagai pelayanan yang akan ditawarkan.

\section{Kualitas Pelayanan}

Kata kualitas memiliki banyak definisi yang berbeda dan bervarinsi dari yang konvensional sampai yang lebih strategis Gasperz (2002) dikutip oleh Wijaya (2011). Definisi konvensional kualitas biasanya menggambarkan karakteristik langsung dari produk seperti, kinerja (Performance), keandalan (reliability), mudah dalam penggunaan (ease of use), estetika (esthetics), dan sebagainya (Wijaya, 2011).

Definisi strategis menyatakan bahwa kualitas adalah segala sesuatu yang mampu 
memenuhi keiniginan atau kebutuhan pelanggan (meeting the needs of customers). Dalam ISO 8420 (quality vocabulary) dikutip oleh (Wijaya, 2011), kualitas didefinisikan sebagai totalitas karakteristiksuatu produk yang menunjang kemampuannya memuaskan kebutuhan yang dispesifikasikan atau ditetapkan. Kualitas sering diartikan sebagai kepuasan pelanggan (customer satisfaction) atau konformansi terhadap kebutuhan atau persyaratan (conformance to the requirements).

Terdapat lima dimensi kualitas jasa dengan menerapkan konsep kesenjangan yang disebut service quality. Lima dimensi kualitas yang dimaksud yaitu (Tjiptono dan Diana 2003 dikutip oleh Wijaya, 2011):

1. Keandalan (Reliability). Adalah kemampuan memberikan pelayanan yang dijanjikan dengan segera, akurat dan memuaskan.

2. Responsiveness (ketanggapan atau kepedulian). Adalah keinginan para staf untuk membantu para pelanggan dan memberikan pelayanan dengan tanggap dan peduli terhadap keluhan atau harapan pelanggan.

3. Assurance (jaminan kepastian). Adalah kompetensi yang sedemikian hingga memberikan rasa aman dari bahaya, risiko, atau keraguan dan kepastian yang mencakup pengetahuan, kesopanan dan sikap dapat dipercaya yang dimiliki staf.

4. Empathy (empathy=empati). Adalah sifat dan kemampuan untuk memberikan perhatian penuh kepada pelanggan, kemudahan melakukan kontak, komunikasi yang baik dan memahami kebutuhan pelanggan secara individual.

5. Berwujud (tangible). Adalah wujud kenyataan secara fisik yang meliputi fasilitas, peralatan, pegawai dan sarana informasi atau komunikasi.

\section{Konsep Pelanggan}

Kata pelanggan adalah istilah yang akrab dengan dunia bisnis di Indonesia mulai dari pedagang kecil hingga pedagang besar, dari industri rumah tangga hingga industri berskala internasional, dari perusahaan yang bergerak di bidang produksi barang hingga perusahaan yang bergerak di bidang jasa. Secara tradisional, pelanggan diartikan orang yang membeli dan menggunakan produksi dalam perusahaan yang bergerak di bidang jasa (Wijaya, 2011).

Pelanggan adalah semua orang yang menuntut perusahaan untuk memenuhi standar kualitas tertentu, dan karena itu akan memberikan pengaruh pada kinerja perusahaan. Manajemen perusahaan L.L. Bean, Freeport, Maine, memberikan beberapa definisi tentang pelanggan, yaitu (Gasperz 2002 dikutip oleh Wijaya, 2011):

1. Pelanggan adalah orang yang tidak tergantung pada kita, tetapi kita yang tergantung padanya.

2. Pelanggan adalah orang yang membawa kita ke keinginannya.

Tidak ada seorang pun yang pernah menang beradu argumentasi dengan pelanggan. Pelanggan adalah orang yang teramat penting harus dipuaskan.

Pada dasarnya dikenal tiga macam pelanggan dalam kualitas modern (Wijaya, 2011):

1. Pelanggan internal (internal customer). Pelanggan internal adalah orang yang berada dalam perusahaan dan memilki pengaruh pada kinerja (performance) pekerja (atau perusahaan kita).

2. Pelanggan antara (intermediate customer). Pelanggan antara adalah mereka yang bertindak atau berperan sebagai perantara, bukan sebagai pemakai akhir produk itu.

3. Pelanggan eksternal (external customer). Pelanggan eksternal adalah pembeli atau pemakai akhir produk itu, yang sering disebut sebagai pelanggan nyata (real customer).

\section{Metode Delphi}

Metode Delphi digunakan dan dipopulerkan pada awal tahun 1960-an oleh RAND, sebuah lembaga penelitian di Santa Monica, California, Amerika Serikat. Metode Delphi merupakan suatu metode yang dilakukan dengan membentuk suatu kelompok atau komunikasi grup yang terdiri dari para ahli untuk membahas suatu permasalahan. Umumnya para ahli yang dilibatkan merupakan para ahli yang memiliki keahlian di bidang permasalahan yang sedang dibahas. Para ahli yang ada tidak saling mengetahui siapa saja yang terlibat di dalamnya sampai nantinya dipertemukan pada tahap akhir dari pelaksanaan metode Delphi ini (Gordon, 1994; Linston and Turrof, 2002 dikutip oleh Sukwadi, 2013).

Umumnya pelaksanaan dari metode Delphi ini dilakukan dalam 4 tahap atau fase sbb (Gordon, 1994 dikutip oleh Sukwadi, 2013):

1. Pada fase pertama kuesioner yang diajukan bertujuan untuk melakukan eksplorasi terhadap hal atau permasalahan yang sedang 
dibahas dengan mengumpulkan informasi secukup mungkin dari kelompok responden.

2. Pengajuan kuesioner fase kedua bertujuan untuk mengetahui pandangan atau pendapat para responden terhadap permasalahan yang sedang dibahas. Pada fase kedua ini hasil yang didapat diteliti apakah terdapat pertentangan pendapat yang signifikan antar kelompok responden mengenai permasalahan yang dibahas.

3. Jika ada pertentangan, maka hal tersebut dijadikan dasar untuk mengetahui alasan mendasar yang menyebabkan pertentangan tersebut melalui pengajuan kuesioner tahap ketiga.

4. Pada fase keempat, seluruh hasil dan jawaban yang telah diperoleh pada tahap sebelumnya dipresentasikan kembali oleh tim kepada para ahli atau kelompok responden untuk dilakukan penyimpulan akhir terhadap permasalahan yang sedang dibahas. Penyampaian hasil yang diperoleh dapat dilakukan dalam bentuk mean atau median data.

\section{Servqual (Service Quality)}

Model kualitas jasa yang paling populer dan hingga kini banyak dijadikan acuan dalam riset manajemen dan pemasaran jasa adalah Servqual (Singkatan dari Service Quality) yang dikembangkan oleh Parasuraman, Zeithaml, dan Berry (1985, 1988, 1990, 1991, 1993, 1994) dalam serangkain penelitian mereka terhadap enam sektor jasa: reparasi peralatan rumah tangga, kartu kredit, asuransi, sumbangan telepon interlokal, perbankan ritel, dan pialang sekuritas. Model yang dikenal pula dengan istilah Gap Analysis Model ini berkaitan erat dengan model kepuasan pelanggan yang didasarkan pada ancaman diskonfirmasi (Oliver, 1997 dikutip oleh Tjiptono, 2011).

\section{Metode Penelitian}

Alur penelitian menguraikan tahapan atau alur yang dijalankan, mulai dari pendahuluan sampai dengan kesimpulan penelitian. Adapun Metodologi penelitian ini dapat dilihat pada Gambar 2.

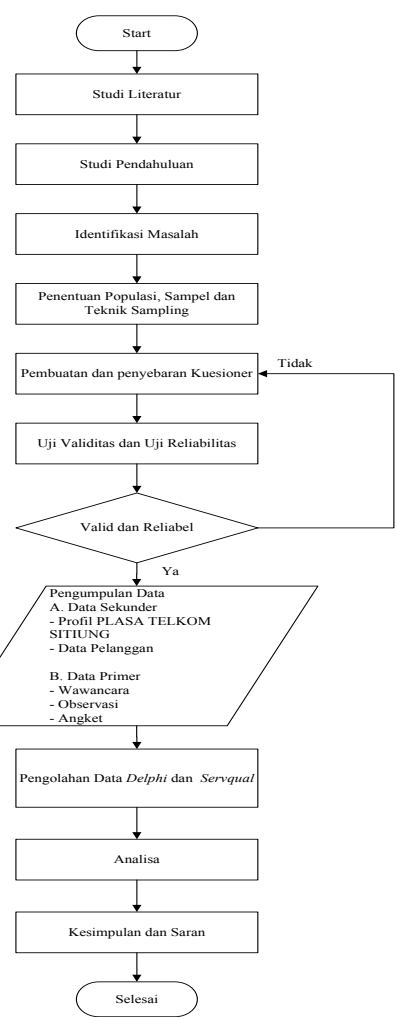

Gambar 2 Flowchart Alur Penelitian

\section{Hasil dan Pembahasan}

\section{Sejarah Singkat dan Profil Perusahaan}

PT. TELKOM adalah Suatu Badan Milik Negara (BUMN) yang bergerak dalam bidang jasa Telekomunikasi. PT TELKOM menyediakan sarana dan jasa layanan Telekomunikasi dan informasi kepada masyarakat luas sampai kepelosok daerah di seluruh Indonesia. Sejarah PT. TELKOM di Indonesia pertama kali berawal dari sebuah badan usaha swasta penyediaan layanan pos dan telegrap yang didirikan kolonial Belanda pada tahun 1882 . Pada tahun 1905 pemerintah kolonial Belanda mendirikan perusahaan Telekomunikasi sebanyak tiga puluh delapan perusahaan. Kemudian Pada tahun 1906 pemerintah Hindia Belanda membentuk suatu jawatan Pos, Telegrap dan Telepon (Post, Telegraph en Telephone Dienst atau PTT).

\section{Struktur Organisasi}

Struktur organisasi PT. TELKOM dapat dilihat pada Gambar 3. 
Vol. 4, No. 2, 2018

Jurnal Hasil Penelitian dan Karya Ilmiah dalam Bidang Teknik Industri

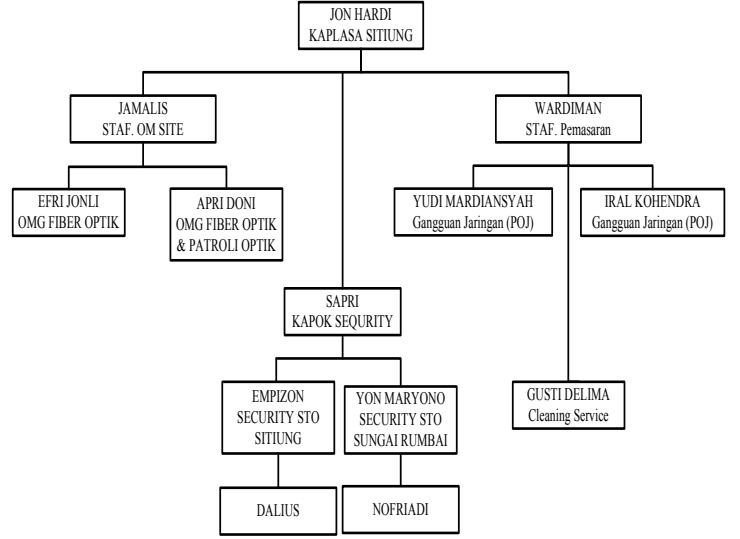

Gambar 3 Struktur Organisasi Kantor Pelayanan Plasa Telkom Sitiung
Pengolahan data pelayanan jasa ini adalah mengukur tingkat kualitas terhadap kepuasan pelanggan PLASA TELKOM SITIUNG dengan menggunakan Metode Servqual. Servqual digunakkan untuk menunjukkan kualitas jasa. Servqual skor (-) negatif menunjukan bahwa terdapat indikasi adanya gap (kesenjangan) kualitas pada atribut kualitas tersebut. Artinya, bahwa nilai Gap yang paling besar merupakan variable pernyataan yang tingkat kepuasan pelanggan terhadapnya sangat rendah. Semakin tinggi nilai gapnya maka semakin tinggi pula keluhan konsumen terhadap variable pernyataan yang ada pada kuesioner. Nilai kinerja dan harapan diperoleh melalui nilai dari rata-rata kuesioner yang kita sebar sebelumnya.

\section{Metode Servqual}

Tabel 1 Nilai Kualitas Pelayanan dengan Metode Servqual

\begin{tabular}{|c|c|c|c|c|}
\hline Ex & Atribut & Persepsi & Harapan & Nilai Servqual (Gap) \\
\hline \multirow{5}{*}{ 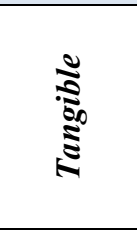 } & 1 & 3,96 & 3,97 & $-0,01$ \\
\hline & 2 & 3,85 & 3,83 & 0,02 \\
\hline & 3 & 3,39 & 3,97 & $-0,58$ \\
\hline & 4 & 3,69 & 4,07 & $-0,38$ \\
\hline & 5 & 3,18 & 4,16 & $-0,98$ \\
\hline \multicolumn{2}{|c|}{ Jumlah } & 18.07 & 20 & -1.93 \\
\hline \multirow{4}{*}{ 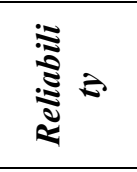 } & 6 & 4,16 & 4,17 & $-0,01$ \\
\hline & 7 & 4,15 & 4,12 & 0,03 \\
\hline & 8 & 3,75 & 4,14 & $-0,39$ \\
\hline & 9 & 3,85 & 3,91 & $-0,06$ \\
\hline \multicolumn{2}{|c|}{ Jumlah } & 15.91 & 16.34 & -0.43 \\
\hline \multirow{3}{*}{ 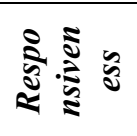 } & 10 & 3,72 & 4,17 & $-0,45$ \\
\hline & 11 & 3,7 & 4,18 & $-0,48$ \\
\hline & 12 & 4,11 & 4,1 & 0,01 \\
\hline \multicolumn{2}{|c|}{ Jumlah } & 11.53 & 12.45 & -0.92 \\
\hline \multirow{3}{*}{ 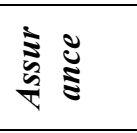 } & 13 & 3,72 & 4,14 & $-0,42$ \\
\hline & 14 & 3,66 & 4,17 & $-0,51$ \\
\hline & 15 & 4,14 & 4,15 & $-0,01$ \\
\hline \multicolumn{2}{|c|}{ Jumlah } & 11.52 & 12.46 & -0.94 \\
\hline \multirow{3}{*}{ 竎 } & 16 & 3,99 & 4,05 & $-0,06$ \\
\hline & 17 & 4,13 & 4,12 & 0,01 \\
\hline & 18 & 4,14 & 4,19 & $-0,05$ \\
\hline \multicolumn{2}{|c|}{ Jumlah } & 12.26 & 12.36 & -0.1 \\
\hline \multicolumn{2}{|c|}{ Total } & 62,29 & 73,61 & $-4,32$ \\
\hline \multicolumn{4}{|c|}{ Rata - rata Keseluruhan Servqual } & $-0,24$ \\
\hline
\end{tabular}

Berdasarkan tabel 1. dapat diketahui nilai Pearson Corelation dan Nilai Sig dari tiap atribut. Pada atribut pelayanan untuk tingkat persepsi dan harapan menunjukkan terdapat 4 atribut yang dihapus yaitu atribut T2, Re12, Res3, E2 karena memiliki nilai Sig besar dari 0 sehingga keempat atribut tersebut dihilangkan. 


\begin{tabular}{|c|c|c|c|c|c|}
\hline $\mathbf{E x}$ & Atribut & Persepsi & Harapan & Nilai Servqual (Gap) & Rangking \\
\hline \multirow{4}{*}{ 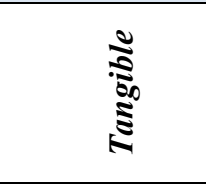 } & 1 & 3,96 & 3,97 & $-0,01$ & \multirow{5}{*}{1} \\
\hline & 3 & 3,39 & 3,97 & $-0,58$ & \\
\hline & 4 & 3,69 & 4,07 & $-0,38$ & \\
\hline & 5 & 3,18 & 4,16 & $-0,98$ & \\
\hline \multicolumn{2}{|c|}{ Jumlah } & 3.56 & 4.04 & -0.48 & \\
\hline \multirow{3}{*}{ 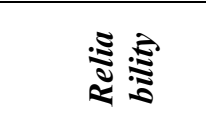 } & 6 & 4,16 & 4,17 & $-0,01$ & \multirow{4}{*}{4} \\
\hline & 8 & 3,75 & 4,14 & $-0,39$ & \\
\hline & 9 & 3,85 & 3,91 & $-0,06$ & \\
\hline \multicolumn{2}{|c|}{ Jumlah } & 3.92 & 4.07 & -0.15 & \\
\hline$\approx \Sigma \bar{z} \approx \tilde{y}$ & 10 & 3,72 & 4,17 & $-0,45$ & \multirow{3}{*}{2} \\
\hline 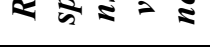 & 11 & 3,7 & 4,18 & $-0,48$ & \\
\hline \multicolumn{2}{|c|}{ Jumlah } & 3.71 & 4.18 & -0.47 & \\
\hline \multirow{3}{*}{ 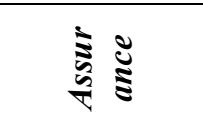 } & 13 & 3,72 & 4,14 & $-0,42$ & \multirow{4}{*}{3} \\
\hline & 14 & 3,66 & 4,17 & $-0,51$ & \\
\hline & 15 & 4,14 & 4,15 & $-0,01$ & \\
\hline \multicolumn{2}{|c|}{ Jumlah } & 3.84 & 4.15 & -0.31 & \\
\hline \multirow{2}{*}{ ฐิฐี่ } & 16 & 3,99 & 4,05 & $-0,06$ & \multirow{3}{*}{5} \\
\hline & 18 & 4,14 & 4,19 & $-0,05$ & \\
\hline \multicolumn{2}{|c|}{ Jumlah } & 4.07 & 4.12 & -0.05 & \\
\hline \multirow{2}{*}{\multicolumn{2}{|c|}{$\frac{\text { Total }}{\text { Rata }- \text { rata Kes }}$}} & 53,05 & 57,44 & $-4,39$ & \\
\hline & & \multicolumn{2}{|c|}{ Rata - rata Keseluruhan $S$} & $-0,24$ & \\
\hline
\end{tabular}

Berdasarkan pengolahan metode servqual di dapatkan hasil nilai rata-rata Gap yaitu -0,24 jika dibandingkan dengan nilai kepuasan pelanggan persepsi dan harapan maka nilai rata-rata Gap kurang dari 0 sehingga nilai kepuasan pelanggan dapat dikatakan Tidak Puas, hal ini disebabkan karena indikator Tangible yaitu kurangnya tindakan nyata yang dilakukan karyawan, Reliability yaitu kurangnya kehandalan karyawan, Responsivines yaitu kuragnya tanggapan karyawn terhadap pelanggan, Assurance yaitu kurangnya kepastian yang diberikan terhadap pelanggan, Empaty yaitu kurangnya respon afektif dan kognitif terhadap pelanggan sehingga hal ini tidak berjalan dengan baik di Plasa Telkom Sitiung.

\section{Kesimpulan}

Kesimpulan yang dapat diambil dalam penelitian ini adalah sebagai berikut :

1. Dengan menggunakan Metode Delphi dan Servqual diketahui bahwa ada 14 atribut kualitas jasa (4 atribut dimensi Tangibles, 3 atribut dimensi Reliability, 2 atribut dimensi Responsiveness, 3 atribut dimensi Assurance, 2 atribut dimensi Emphaty) yang diinginkan oleh pelanggan untuk ditingkatkan.
2. Berdasarkan analisis Gap, semua skor Gap bernilai negatif sehingga tiap dimensi kualitas jasa masih perlu untuk diperbaiki dan ditingkatkan. Dimensi kualitas jasa yang mendapatkan prioritas untuk diperbaiki/ditingkatkan adalah dimensi Tangibles (selisih nilai Gap -0,48) dan dimensi Responsivines (selisih nilai Gap -0,47)

3. Dari 14 atribut, prioritas utama yang perlu ditingkatkan dan dikembangkan adalah atribut perlengkapan dalam memberikan pelayanan lengkap dan berfungsi dengan baik dengan nilai Gap -0,98 dari dimensi Tangible (kode atribut T5). Karena memiliki nilai Gap terbesar dari semua atribut yang telah dilakukan pengolahan dengan nilai persepsi yaitu 3,18 dan harapan yaitu 4,16.

\section{Daftar Pustaka}

[1] Handriati, A.Z. Analisis Kualitas Pelayanan Publik Terhadap Kepuasan Konsumen dengan Menggunakan Metode SERVPERF-IPA-CSI. Teknoin Vol. 21 No. 4 Hal. 178-190 Desember 2015.

[2] Kriesniati, P. Analisis Korelasi Somers'd pada data Tingkat Kenyamanan Siswa-Siswi SMP Plus Melati Samarinda. Jurnal barekeng Vol. 7 
No. 2 Hal. 31-40. 2013.

[3] Nugraha, R. Usulan Peningkatan Kualitas Pelayanan Jasa pada Bengkel X berdasarkan Matrix Importance Performance Analysis (Studi kasus di Bengkel AHASS PD. Sumber Motor Krawang). Jurnal Online Institut Teknologi Nasional Vol.1 No.3 Hal. 221-231 Januari 2014.

[4] Purnamawati, E. Analisis Kualitas Layanan dengan Metode Servqual dan AHP di Dinas Kependudukan dan Pencatatan Sipil di Surabaya. Teknik Industri FTI-UPN 2014.(http://ejournal.upnjatim.ac.id/index.php ttekmapro/article/download/ diakses tanggal 22 Mei 2016).

[5] Riduwan. 2004. Belajar Mudah Penelitian untuk Guru-Karyawan dan Peneliti Pemula. Bandung : Penerbit ALFABETA

[6] Suliyanto. 2006. Metode Riset Bisnis. Yogyakarta: C.V Andi Offset.

[7] Sukwadi, R. Pengembangan Model Integrasi DELPHI-AHP-MARKOV dalam Perencanaan Kebutuhan Sumber Daya Manusia. Jurnal Spektrum Industri Vol. 11 No.2 Hall117-242 2013

[8] Tjiptono.F. 2011. Service Quality \& Satisfaction. Yogyakarta: Penerbit Andi

[9] Wijaya T, 2011. Manajemen Kualitas Jasa. PT. Indeks. 